\title{
Three new species of Persoonia (Proteaceae) from Queensland
}

\author{
Peter H. Weston \& L.A.S. Johnson
}

\begin{abstract}
Weston, Peter H. E Johnson, L.A.S. (National Herbarium of New South Wales, Royal Botanic Gardens, Sydney, Australia 2000) 1994. Three new species of Persoonia (Proteaceae) from Queensland. Telopea 6(1): 31-37. Three new species are described: Persoonia tropica P.H. Weston \& L.A.S. Johnson, P. iogyna P.H. Weston \& L.A.S. Johnson, and P. queenslandica P.H. Weston \& L.A.S. Johnson.
\end{abstract}

\section{Introduction}

In the course of our revisionary work on Persoonia in eastern Australia we have recognised the existence of three new species endemic in Queensland. In this paper we formally name these to make the names available for the forthcoming volume 16 of Flora of Australia. Definitions of descriptive terms are as discussed by Weston \& Johnson (1991) and Weston (1994). Codes used to indicate conservation status follow the conventions of Briggs \& Leigh (1988).

All three species share the following characters, in common with all other eastern Australian species except $P$. falcata: anther appendages absent, flowers virtually actinomorphic (the gynoecium appears radially symmetrical, although consisting of one carpel), and gynoecium almost as long as the tepals.

Persoonia tropica P.H. Weston \& L.A.S. Johnson, sp. nov.

Pili $0.05-0.4 \mathrm{~mm}$ longi, adpressi. Folia anguste elliptica vel oblanceolata, $4.5-11 \mathrm{~cm}$ longa, 7-21 mm lata, marginibus recurvis. Inflorescentiae terminales vel subterminales, anauxotelicae. Flores regulares. Pedicelli $0.5-2 \mathrm{~mm}$ longi. Antherae sine appendice. Ovarium glabrum. Ovula 2.

Holotype: Queensland: North Kennedy: $6 \mathrm{~km}$ from Koombooloomba Dam on road to Tully Falls, $17^{\circ} 49^{\prime} 30^{\prime \prime}$ S $145^{\circ} 33^{\prime} 40^{\prime \prime}$ E, P. Hind 6421 \& C. Herscovitch, 18 Sep 1991 (NSW). Isotypes: BRI, CANB, K, MO.

Erect shrubs or small trees, 2-3.5 m high, with smooth, grey bark. Hairs $0.05-0.4 \mathrm{~mm}$ long, greyish to mid-brown, appressed. Young branchlets moderately hairy; internodes $0-25(-55) \mathrm{mm}$ long. Leaves alternate, narrow-elliptical to oblanceolate, acuminate, (0.6-)4.5-11 cm long, (2-)7-21 mm wide, flat with recurved margins, spreading to suberect, symmetrical, not twisted, not pungent, slightly discolorous, green but turning brown to black on drying, sparsely to moderately hairy when immature, retaining hairs towards the base but otherwise usually glabrescent when mature, smooth; venation brochidodromous, evident on the adaxial surface, less so or obscure on the abaxial surface. Inflorescences terminal or subterminal, anauxotelic, 3-10-flowered; rachis $0.3-1.0 \mathrm{~cm}$ long; flowers subtended by scale leaves or reduced leaves. Pedicels $0.5-2 \mathrm{~mm}$ long, erect, moderately to densely hairy. Tepals $9-11 \mathrm{~mm}$ long, acute, sparsely hairy, yellow. Anthers held close to one another and to the gynoecium at their bases but slightly recurved at the tips, yellow but paler than the tepals; loculi 3-4.5 mm long. Gynoecium 7.5-9 mm long; ovary glabrous; ovules 2. 
Drupes green to pale yellow; pyrene ellipsoidal, compressed, 9-11.5 mm long, 5.5$6 \mathrm{~mm}$ wide. Seed 1; cotyledons 2 or 5-6. Fig. 1.

Derivation of epithet: from Latin tropicus, tropical. This is the only species of Persoonia that is restricted to the tropics.

Flowering period: Throughout the year but flowering most prolifically in Spring.

Habitat: Dry to wet sclerophyll forest, on soils derived from granite, metasediments or rhyolite, from 700 to $1200 \mathrm{~m}$ altitude.

Distribution: Herberton Range, the Ravenshoe area and the catchment of the upper Tully River, Queensland (Fig. 2).

\section{Proposed conservation status: $2 \mathrm{~K}$.}

Notes: This species most closely resembles $P$. media $\mathrm{R}$. Br. and $P$. amaliae Domin. It is distinguished from both of those species by its consistently anauxotelic inflorescences ( $P$. amaliae has consistently auxotelic inflorescences and $P$. media has either auxotelic or a mixture of auxotelic and anauxotelic inflorescences), its short, 0.5-2 mm long pedicels (3-10 $\mathrm{mm}$ long in $P$. media, $3-9 \mathrm{~mm}$ long in $P$. amaliae), and its ovary containing two ovules (one ovule in both $P$. media and $P$. amaliae).

Two specimens (Hyland 14097 \& 14098), from the southern part of the distribution, have embryos with two cotyledons, unlike specimens from the Herberton Range and the Ravenshoe area, which have five to six cotyledons. It remains to be seen whether this variation is geographically correlated. This is the most striking example of intraspecific variation in cotyledon number yet found in the Persooniinae. Toronia toru (Cunn.) L.A.S. Johnson \& B.G.Briggs is known to produce seeds with two or three cotyledons (Mueller 1882, pers. obs.). Although other species with multiple cotyledons usually show variation in cotyledon number, none are known to produce

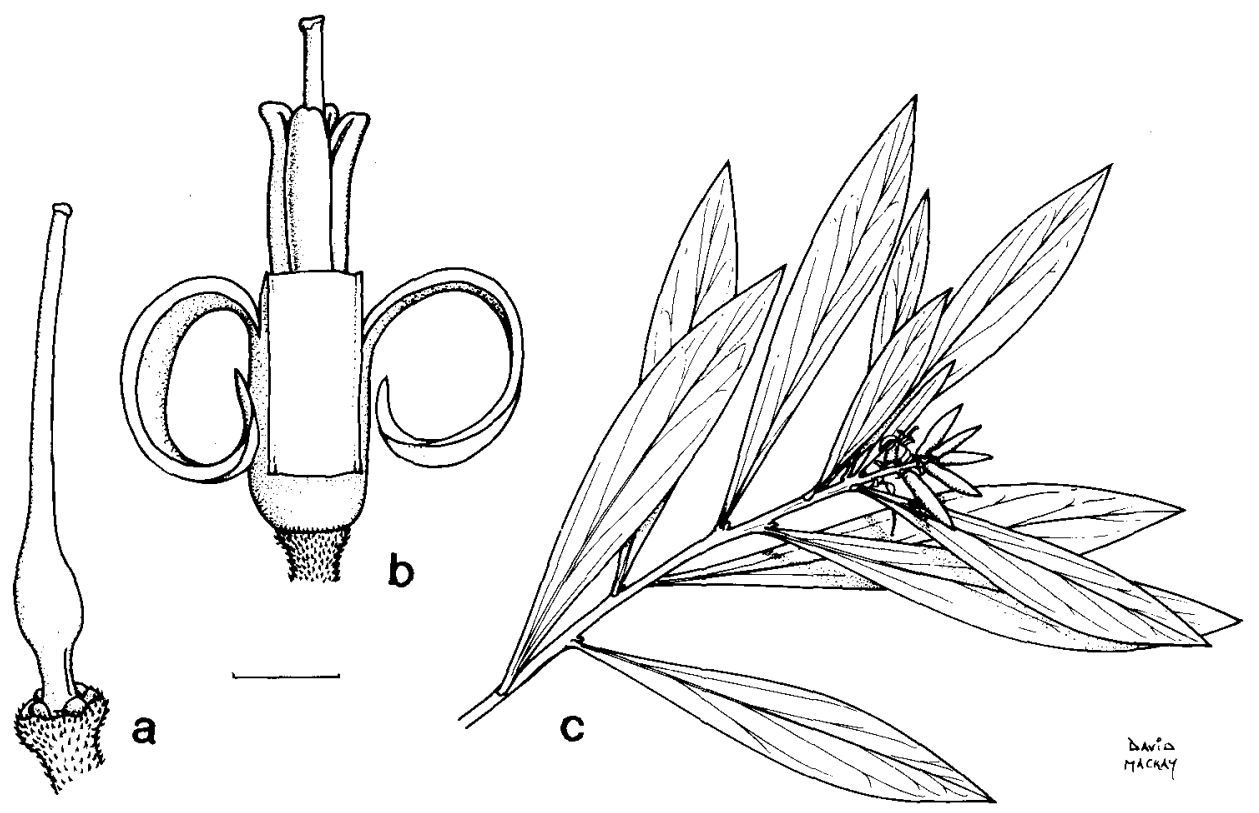

Figure 1. Persoonia tropica. a, gynoecium, hypogynous glands and tip of pedicel; b, flower; $\mathbf{c}$, habit (from Hind $6421 \&$ Herscovitch). Scale bar: $a, b=2 \mathrm{~mm} ; \mathrm{c}=18 \mathrm{~mm}$. 
seeds with two cotyledons as well (Fletcher 1908, unpublished data). The other 10 species that produce seeds with two cotyledons are invariant for this character (unpublished data).

Selected specimens (13 collections examined): Queensland: North Kennedy: $1.3 \mathrm{~km} \mathrm{SW}$ of Wallum Trig, Herberton Range, $17^{\circ} 16^{\prime} \mathrm{S} 145^{\circ} 23^{\prime} \mathrm{E}$, Weston 1791-1792 \& Brown, Jul 1994 (NSW, BRI); $5.5 \mathrm{~km}$ N of Ravenshoe, $17^{\circ} 33^{\prime} \mathrm{S} 145^{\circ} 29^{\prime} \mathrm{E}$, Weston 1787-1790, Brown, Lockyer \& Mogea, Jul 1994 (NSW, BRI); Spur near Bald Rock, 2.6 km W of Ravenshoe, Lockyer s.n., Jan 1978 (BRI); State Forest Reserve 756, Ismailia, Muggera Logging Area, $3 \mathrm{~km} \mathrm{~S}$ of Tully Falls turn-off, $17^{\circ} 48^{\prime} \mathrm{S} 145^{\circ} 33^{\prime} \mathrm{E}$, Hyland 14097-14098, Jan 1991 (BRI, NSW, QRS); Limestone Creek, Culpa area, Atkinson s.n., Jul 1937 (BRI).

\section{Persoonia iogyna P.H. Weston \& L.A.S. Johnson, sp. nov.}

Pili $0.1-0.4 \mathrm{~mm}$ longi, antrorsi ad adpressi. Folia anguste elliptica vel lanceolata vel oblanceolata, $2.5-11 \mathrm{~cm}$ longa, $6-19 \mathrm{~mm}$ lata, marginibus recurvis. Inflorescentiae terminales vel axillares, auxotelicae vel anauxotelicae. Flores regulares. Pedicelli 2-5 mm longi. Antherae sine appendice. Ovarium modice ferrugineo-pilosiusculum. Ovulum 1.

Holotype: Queensland: Moreton: Mt Glorious Road, $8.1 \mathrm{~km} \mathrm{NNW}$ of Mt Nebo, 1.0

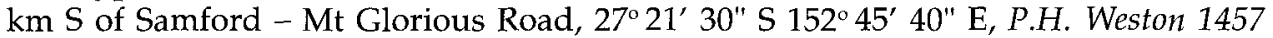
E P.G. Richards, 5 Jan 1990 (NSW). Isotypes: AD, BRI, CANB, DNA, HO, K, MEL, MO, NSW, QRS.

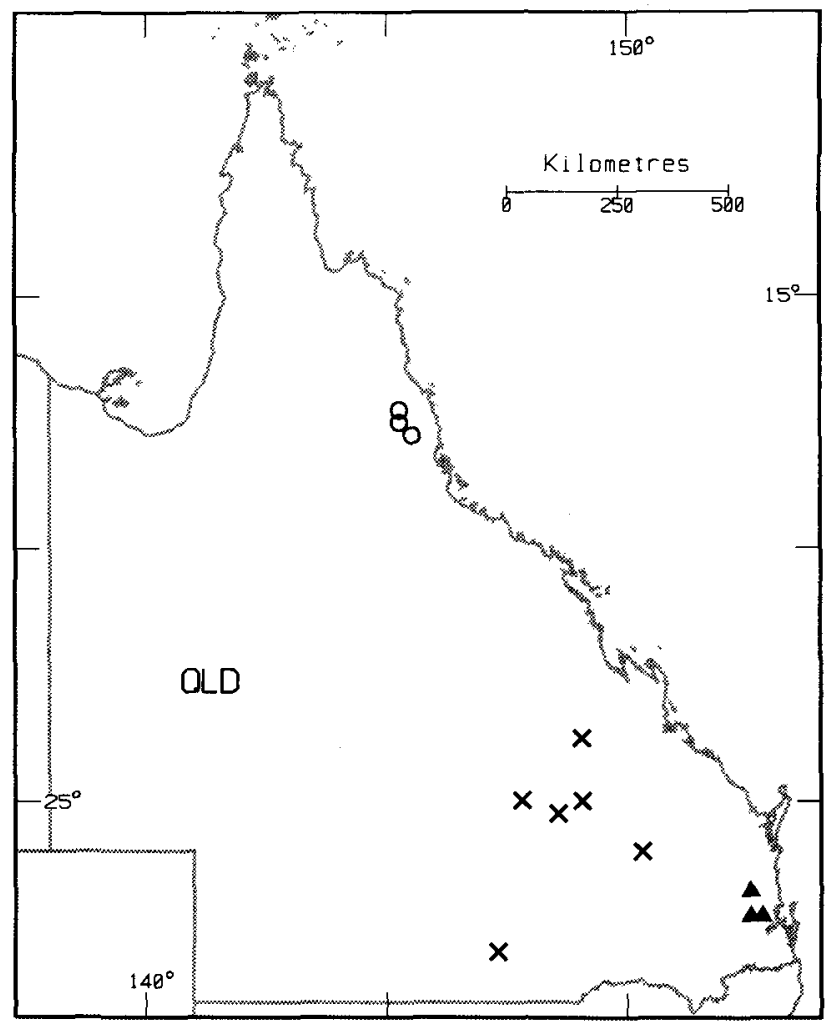

Figure 2. Distributions of Persoonia tropica (o), P. iogyna (x), and P. subtilis (s); all symbols represent presence of one or more collection localities in a $15 \times 15$ minute grid square. 
Erect shrubs or small trees, 1.6-4 m high, with smooth, grey bark. Hairs mostly $0.1-$ $0.4 \mathrm{~mm}$ long, ferruginous, antrorsely spreading (branchlets, pedicels and tepals) or appressed (gynoecium and immature leaves). Young branchlets moderately hairy; internodes $0-19(-43) \mathrm{mm}$ long. Leaves alternate, narrow-elliptical to lanceolate to oblanceolate, acuminate, (1.1-)2.5-11 cm long, (3.5-)6-19 mm wide, flat with recurved margins, spreading, symmetrical, not twisted, not pungent, slightly to strongly discolorous, green but turning brown on drying, sparsely hairy when immature, often retaining hairs towards the base but otherwise glabrescent when mature, smooth; venation brochidodromous, evident on the adaxial surface, less so or obscure on the abaxial surface. Inflorescences terminal to axillary, auxotelic (20$100 \%$ ) or anauxotelic (0-80\%); auxotelic inflorescences 1-11-flowered, rachis $0-5.5$ $\mathrm{cm}$ long, flowers subtended basally by scale leaves and more distally by leaves; anauxotelic inflorescences 1-4-flowered, rachis $0-0.5 \mathrm{~cm}$ long, flowers subtended by scale leaves. Pedicels 2-5 mm long, erect, sparsely to moderately hairy. Tepals 10-13 $\mathrm{mm}$ long, shortly caudate, sparsely to moderately hairy, yellow. Anthers held close to one another and to the gynoecium at their bases but slightly recurved at the tips, yellow; loculi 3.5-5.5 mm long. Gynoecium 8.5-11.5 mm long; ovary moderately to densely covered in ferruginous hairs; ovule 1. Drupes green; pyrene ellipsoidal, c. 9 $\mathrm{mm}$ long, c. $4.5 \mathrm{~mm}$ wide. Seed 1; cotyledons 4-5. Fig. 3.

Derivation of epithet: from Greek ios, rust, and gyne, a woman, referring to the ferruginous-hairy ovary.

Flowering period: December to February.

Habitat: Dry to wet sclerophyll eucalypt forest, on soils derived from metasediments, at altitudes ranging from 400 to $600 \mathrm{~m}$.

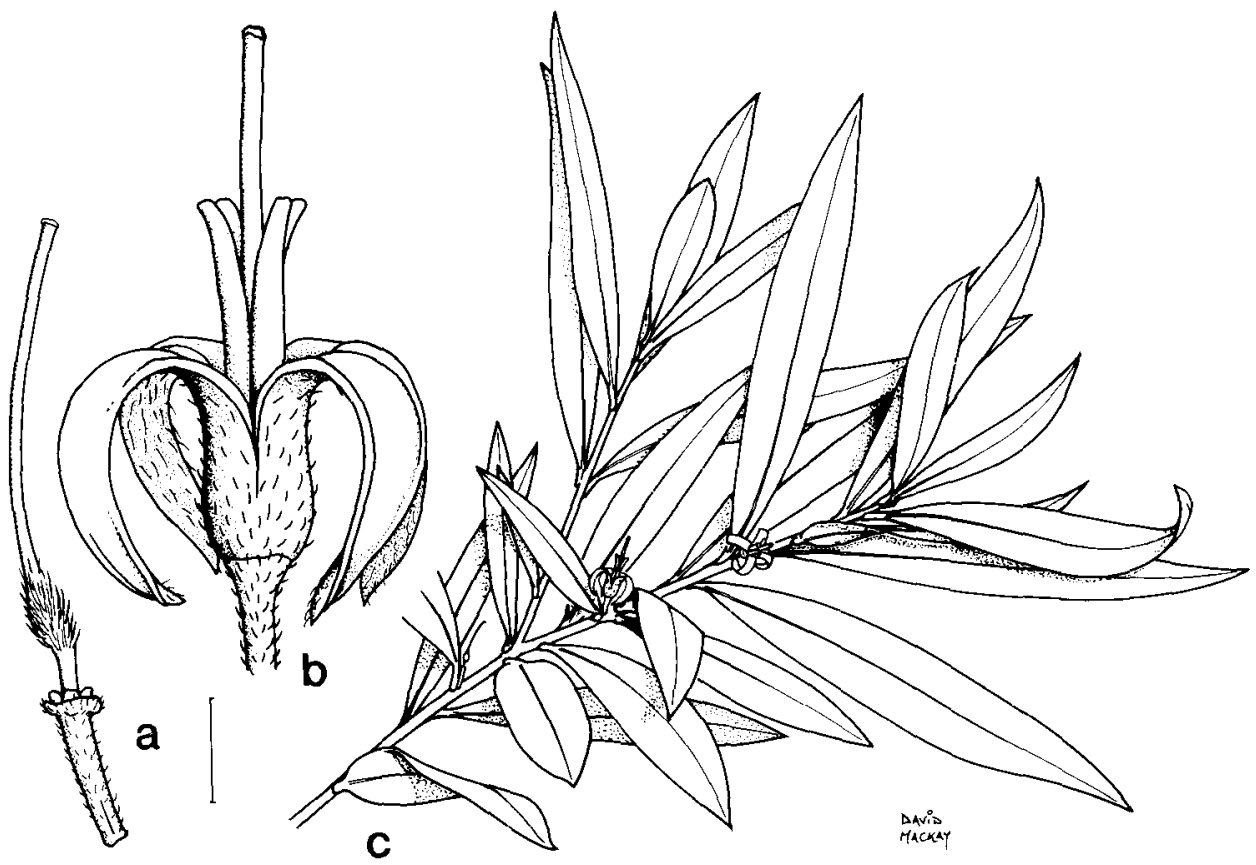

Figure 3. Persoonia iogyna. a, gynoecium, hypogynous glands and tip of pedicel; $\mathbf{b}$, flower; $\mathbf{c}$, habit (from Weston $1457 \&$ Richards). Scale bar: $\mathbf{a}, \mathbf{b}=2 \mathrm{~mm} ; \mathrm{c}=18 \mathrm{~mm}$. 
Distribution: Conondale and D'Aguilar Ranges, south-eastern Queensland (Fig. 2).

Proposed conservation status: $2 \mathrm{RC}$.

Notes: This species most closely resembles $P$. media $\mathrm{R}$. Br. (occurring on the Springbrook and Lamington plateaux in extreme south-eastern Queensland and more extensively in New South Wales), P. conjuncta P.H. Weston \& L.A.S. Johnson (occurring in New South Wales between the Bellinger and Manning Rivers), and P. oleoides L.A.S. Johnson \& P.H. Weston (occurring in New South Wales between the upper Clarence River and the upper Macleay River). It is distinguished from all of those species by its consistently ferruginous-hairy ovary $(P$. media and $P$. oleoides both usually have glabrous ovaries but a few specimens of both those species and all specimens of $P$. conjuncta have greyish-hairy ovaries). In addition, $P$. iogyna differs from $P$. media in having moderately antrorse-hairy branchlets $(P$. media has sparsely appressed-hairy branchlets), from $P$. conjuncta in its smooth bark (in $P$. conjuncta the bark on the trunk is finely but consistently fissured), and from $P$. oleoides in its larger size ( $P$. oleoides grows to only $1.0 \mathrm{~m}$ high).

Stanley and Ross (1986) treated P. iogyna as a form of $P$. attenuata R. Br., in accordance with annotations that we had made on specimens held by BRI. However, they commented that:

There are at least two taxa under this name: one completely glabrous, the other with scattered coarse reddish hairs. In addition to these forms there is a shrubby form with small leaves ca $5 \mathrm{~cm} \times 0.5 \mathrm{~cm}$ and soft whitish or reddish hairs found on Mt Barney, Mt Maroon and Mt Ernest in the southern Moreton district, growing among boulders in rocky areas towards the top of the mountains. This taxon requires further study. (Stanley \& Ross 1986: 9).

The holotype of $P$. attenuata $\mathrm{R}$. Br. is a specimen of the hybrid $P$. stradbrokensis Domin $x P$. virgata $\mathrm{R}$. Br. and so this name is not applicable to any of the species in this group (Weston \& Johnson 1991). It is clear, from the distributional notes that Stanley and Ross appended to their treatment of $P$. attenuata, that their concept subsumed four species: (i) P. iogyna, (ii) P. media, (iii) P. volcanica P.H. Weston \& L.A.S. Johnson (Mt Barney, Mt Maroon, Mt Ernest and the MacPherson Range between Levers Plateau and Wilsons Peak, along the eastern part of the QueenslandNew South Wales border, as well as on the Kroombit Tops, south-west of Gladstone, Queensland), and (iv) P. amaliae Domin (endemic in Queensland, occurring on coastal and near-coastal ranges from the Eungella area, west of Mackay, to the Coast Range, south of Biggenden).

Selected specimens (14 collections examined): Queensland: Wide Bay: $0.3 \mathrm{~km} \mathrm{~N}$ of Bellthorpe forestry office, $26^{\circ} 49^{\prime} \mathrm{S} 152^{\circ} 41^{\prime} \mathrm{E}$, Weston 1465, 1466 \& Richards, Jan 1990 (NSW, BRI); $10 \mathrm{~km}$ from Bellthorpe, towards Conondale Ranges, $26^{\circ} 49^{\prime} \mathrm{S} 152^{\circ} 41^{\prime}$ E, Bean 933, Sep 1988 (BRI, NSW). Moreton: $6.3 \mathrm{~km}$ beyond Mt Glorious, along Wivenhoe Dam road, Bean 1012, Feb 1989 (NSW); One Mile Creek, Lawnton, Blake 2161, Jan 1931 (BRI); type locality, Weston 1458-1460 \& Richards, Jan 1990 (NSW); Mt Glorious, Clemens s.n., Jan 1945 (BM, BRI, L).

Persoonia subtilis P.H. Weston \& L.A.S. Johnson, sp. nov.

Frutices multicaules patuli vel decumbentes. Pili $0.15-1.0 \mathrm{~mm}$ longi, adpressi vel antrorsi. Ramuli novelli modice pilosi. Folia linearia, $1.5-5 \mathrm{~cm}$ longa, $0.4-0.8 \mathrm{~mm}$ lata, subteretia, infra canaliculata. Flores regulares. Pedicelli $2-8 \mathrm{~mm}$ longi, patentes vel recurvi. Tepala modice pilosa. Antherae flavae, sine appendice. Ovarium dense pilosum. Ovula 2.

Holotype: Queensland: Leichhardt: Falls on Mimosa Creek, next to camping area, Blackdown Tableland, 23 48' 00" S 149 04' 30" E, P.H. Weston 1539 \& P.G. Richards, 
12 Jan 1990 (NSW). Isotypes: AD, BRI, CANB, DNA, HO, K, MEL, MO, QRS.

Spreading to decumbent shrub with many stems branching from below ground level, $0.15-1.0 \mathrm{~m}$ high, without well-developed bark, regenerating from a lignotuber after disturbance. Hairs mostly $0.15-1.0 \mathrm{~mm}$ long, greyish to tawny, mostly appressed to antrorsely spreading. Young branchlets moderately covered with antrorse hairs; internodes $0-10(-16) \mathrm{mm}$ long. Leaves alternate, linear, acute to acuminate, (0.5-)1.5-5 cm long, 0.4-0.8 mm wide, subterete, grooved underneath, slightly recurved to strongly incurved, spreading to erect, symmetrical, not pungent, bright green but turning dull green to dark grey on drying, moderately hairy when immature, glabrescent to moderately hairy when mature, slightly to moderately scaberulous; venation obscure. Inflorescences terminal to axillary, mostly auxotelic, 1-18-flowered; rachis up to $5 \mathrm{~cm}$ long; flowers subtended by scale leaves and leaves. Pedicels $2-8 \mathrm{~mm}$ long, spreading to recurved, moderately hairy. Tepals 7-10 mm long, acute to apiculate, moderately hairy, yellow. Anthers held close to one another and to the gynoecium at their bases but recurved towards the tips, yellow; loculi 3-5 mm long. Gynoecium 6-9 mm long; ovary densely covered with appressed hairs; ovules 2 . Drupes green with longitudinal purple stripes; pyrene ovoid to ellipsoid, 7.5-9 mm long, 5-6 mm wide. Seed 1; cotyledons 6-7. Fig. 4.

Derivation of epithet: from Latin subtilis, slender, fine, alluding to the linearfiliform leaves.

Flowering period: November to January with inflorescences sporadically occurring as late as April.

Habitat: Dry sclerophyll forest or woodland on sandy soils derived from sandstone or sandy alluvium, at altitudes ranging from 200 to $900 \mathrm{~m}$; locally common.
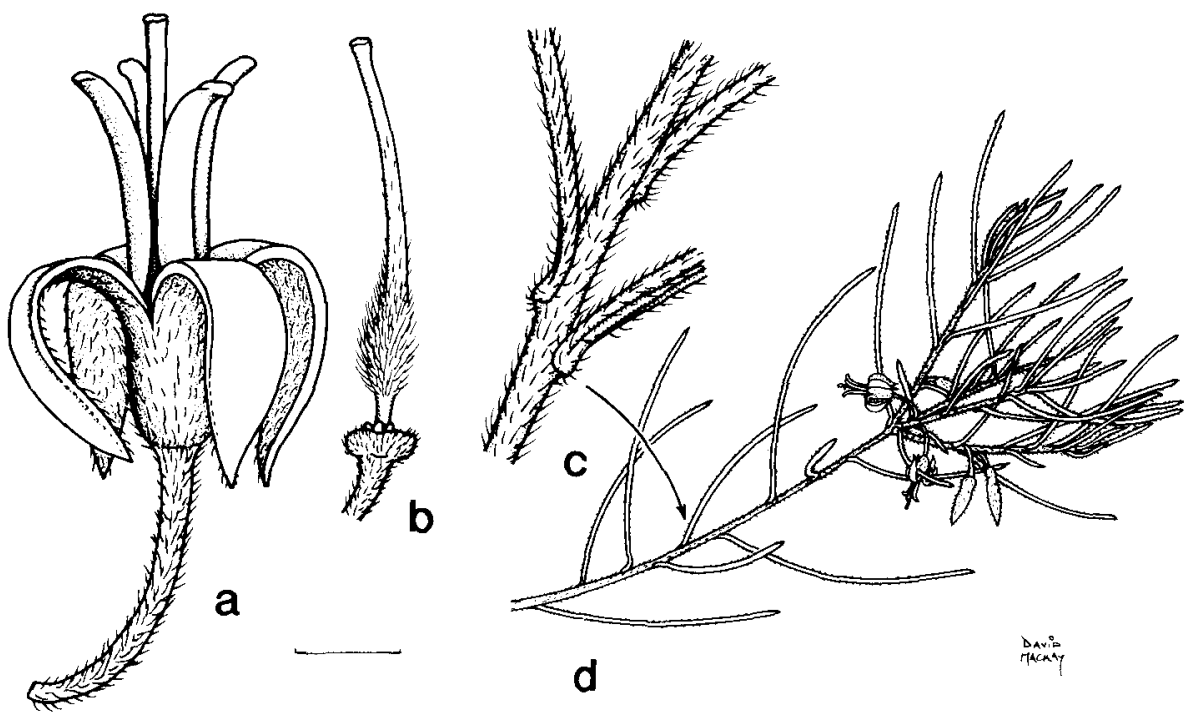

Figure 4. Persoonia subtilis. a, flower; b, gynoecium, hypogynous glands and tip of pedicel; $\mathbf{c}$, detail of stem and leaf-bases; $\mathbf{d}$, habit (from Weston $1539 \mathcal{E}$ Richards). Scale bar: $\mathbf{a}-\mathbf{c}=2 \mathrm{~mm}$; $=18 \mathrm{~mm}$. 
Distribution: Disjunctly distributed in an area bounded by the Blackdown Tableland, Carnarvon Range, Bollon and Barakula, south-eastern Queensland (Fig. 2).

Habitat: Not rare.

Notes: This species closely resembles $P$. fastigiata, a species that is restricted to granitic soils in north-eastern New South Wales. It is distinguished from that species by its indumentum of appressed to antrorsely spreading hairs (mostly patent in $P$. fastigiata except for antrorsely spreading gynoecium hairs) and its narrower leaves (0.75-2 mm wide in $P$. fastigiata).

Specimens of $P$. subtilis are somewhat variable in leaf length but variation within populations seems as great as that between them.

Selected specimens (25 collections examined): Queensland: Leichhardt: Mimosa Creek near forestry camp, Blackdown Tableland, Blaxell 809, Nov 1972 (BRI, CANB, NSW); Near Bedourie Homestead, Story \& Yapp 282, Sep 1962 (CANB, NSW); 3rd crossing of Dawson River, $61 \mathrm{~km} \mathrm{~N}$ of Injune, $2^{\circ} 21^{\prime} \mathrm{S} 148^{\circ} 38^{\prime} \mathrm{E}$, Hill 1210, Johnson \& Bean, Aug 1984 (NSW, BRI, PERTH); Waaje area, $26^{\circ} 09^{\prime} \mathrm{S} 150^{\circ} 20^{\prime}$ E, Bean 546. Apr 1987 (BRI, NSW). Maranoa: Mt Moffat section of Carnarvon National Park, 25 02' S $147^{\circ} 57^{\prime}$ E, Thomas 80, Sep 1986 (BRI); Bollon State Forest, $28^{\circ} 02^{\prime} \mathrm{S} 147^{\circ} 29^{\prime} \mathrm{E}$, Nielsen 25, Aug 1971 (BRI).

\section{Acknowledgements}

A. Bean, C. Herscovitch, P. Hind, B. Hyland and A. Irvine kindly collected material for this study and provided useful field observations. M. Lockyer kindly helped us to find and collect P. tropica. E. Brown and P. Richards assisted in the field. D. Mackay drew the illustrations and D. Godden drafted the map. B. Briggs, J. Everett, R. Henderson and P. Wilson provided helpful comments on earlier drafts of the manuscript. We are grateful to the Director of BRI for providing specimens of Persoonia on loan.

\section{References}

Briggs, J.D., \& Leigh, J.H. (1988) Rare or Threatened Australian Plants, 1988 revised edition (Australian National Parks and Wildlife Service: Canberra).

Fletcher, J.J. (1908) Illustrations of polycotyledony in the genus Persoonia, with some reference to Nuytsia. Proc. Linn. Soc. New South Wales 33: 867-881.

Mueller, F. (1882) Plurality of cotyledons in the genus Persoonia. New Zealand J. Sci. 1: 115-117.

Stanley, T.D. \& Ross, E.M. (1986) Flora of South-eastern Queensland, vol. 2 (Queensland Department of Primary Industries: Brisbane).

Weston, P.H. (1994) The Western Australian species of Persooniinae (Proteaceae). Telopea 6: 51165.

Weston, P.H. \& Johnson, L.A.S. (1991) Taxonomic changes in Persoonia (Proteaceae) in New South Wales. Telopea 4: 269-306. 